\title{
HISTORIA HISTORIOGRAFII A CELE I WARTOŚCI TOWARZYSZACECE STUDIOWANIU HISTORII
}

Wiktor WERNER

\section{ABSTRACT}

\section{TEACHING OF THE HISTORY OF HISTORIOGRAPHY IN RELATION TO OBJECTIVES AND}

\section{VALUES ACCOMPANYING STUDYING THE HISTORY}

The article discusses the issue of teaching the history of historiography in the context of the values and goals that students of history declare as important to them. Based on the survey, it can be stated that for the students of history at AMU two important values are prevalent: intellectual development and work for the benefit of society (understood as the commemoration of things worth remembering). It is also important for them to acquire skills useful in future work. "The history of historiography" as an academic subject may enable the realization of these values and goals. A lecturer in the history of historiography can show students the relationship of historical knowledge to social problems. She/he can also introduce modern methods of data analysis to present the problem of reception of historiography in the modern world.

\section{KEYWORDS:}


Celem poniższego artykułu jest dokonanie refleksji nad zagadnieniem prowadzenia zajęć z przedmiotu „Historia historiografii”. Namysłu zamierzamy dokonać w oparciu o własne doświadczenie dydaktyczne oraz analizę danych dotyczących deklarowanych przez studentów celów i wartości związanych ze studiowaniem historii. Dane pochodzą z badań ankietowych, których szczegółowa prezentacja i omówienie zostały umieszczone w załączeniu do artykułu (DODATEK 1). Ankieta została przeprowadzona w roku 2016 wśród siedemdziesięciu studentów I roku historii (w Instytucie Historii UAM). W ramach ankiety studenci odpowiadali na pytania dotyczące wartości i celów towarzyszących studiowaniu i sporządzaniu pracy dyplomowej.

Treść pytań:

1. Proszę odnieść się do następującego twierdzenia: „studiuję, dla uzyskania dyplomu - więcej mnie nic nie interesuje.”

2. Proszę odnieść się do następującego twierdzenia: „studiuję, aby dowiedzieć się jak najwięcej o świecie, rozszerzyć swoje horyzonty."

3. Proszę odnieść się do następującego twierdzenia: „studiuję po to, by poznać ciekawych ludzi, rozszerzyć kontakty towarzyskie”.

4. Proszę odnieść się do następującego twierdzenia: „studiuję, gdyż jest to przyjemny sposób spędzania czasu."

5. Proszę odnieść się do następującego twierdzenia: „studiuję, gdyż mam nadzieję, że dzięki temu będę mogła/mógł zrobić coś pożytecznego dla innych.”

6. Proszę odnieść się do następującego twierdzenia: „piszę pracę dyplomową, aby mieć to z głowy."

7. Proszę odnieść się do następującego twierdzenia: „piszę pracę dyplomową, aby odkryć coś nowego i jej jakość jest dla mnie bardzo ważna.”

8. Proszę odnieść się do następującego twierdzenia: „piszę pracę dyplomową, po to aby rozwinąć się intelektualnie."

9. Proszę odnieść się do następującego twierdzenia: „piszę pracę dyplomową, po to, by zdobyć sławę i uznanie.”

10. Proszę odnieść się do następującego twierdzenia: „piszę pracę dyplomową, aby wskazać na ważne problemy wymagające rozwiązania.”

11. Proszę odnieść się do następującego twierdzenia: „piszę pracę dyplomową, aby upamiętnić ludzi i wydarzenia, które nie powinny zostać zapomniane.”

12. Proszę odnieść się do następującego twierdzenia: „piszę pracę dyplomową, aby zdobyć kwalifikacje, które będą mi przydatne na rynku pracy." 
13. Proszę odnieść się do następującego twierdzenia: „piszę pracę dyplomową, aby odnieść w ten sposób korzyści finansowe."

14. Proszę odnieść się do następującego twierdzenia: „piszę pracę dyplomową, gdyż sprawia mi to przyjemność, dobrze się bawię."

$\mathrm{W}$ odniesieniu do każdego z pytań mogła paść jedna z następujących odpowiedzi:

1. Utożsamiam się z tym stwierdzeniem

11. Nie utożsamiam się z tym stwierdzeniem, ale nie jest ono mi zupełnie obce

111. Zupełnie odrzucam ten punkt widzenia

IV. Trudno powiedzieć, nie wiem.

Na podstawie udzielonych przez studentów odpowiedzi można zauważyć przewagę postawy pro-jakościowej przejawiającej się w silnej identyfikacji z wartościami deklarowanymi w pytaniach 2, 8 i 12 (większość odpowiedzi l) a jednocześnie zdystansowania się od „wartości” wskazanej w pytaniach 1 i 6 (większość odpowiedzi 111). Ankietowani zadeklarowali również pozytywną relację do etycznych wartości towarzyszących studiowaniu poprzez identyfikację z wartościami zasygnalizowanymi w pytaniach $5 \mathrm{i} 11$.

Możemy zatem przypuszczać, że prowadząc zajęcia z „Historii historiografii” nie będziemy mieli do czynienia z osobami przypadkowymi, lecz ze studentami, którzy podjęli się trudu zdobywania wykształcenia historycznego w sposób świadomy, gdyż ich wartości i cele, które deklarują są silnie skorelowane z wartościami związanymi z efektami kształcenia obecnymi na kierunku historia. Orientacja pro-jakościowa studentów niewątpliwie cieszy, lecz jest także niemałym wyzwaniem dla prowadzącego zajęcia, który stoi przed trudnym zadaniem zaspokojenia zróżnicowanych oczekiwań studentów względem zajęć, które mają nie tylko przekazać wiedzę związaną ze specyfiką przedmiotu oraz studiowanego kierunku, lecz również rozwinąć intelektualnie, a ponadto tak pokierować uczestnikami zajęć, by w w toku studiowania i prac nad pracą dyplomową nabyli umiejętności cenione na rynku pracy. Niewątpliwie stworzenie programu zajęć, które realizowałyby taki konglomerat oczekiwanych efektów w przypadku większości przedmiotów nauczanych w ramach studiów historycznych jest nadzwyczaj trudne, a często wręcz niemożliwe. Jednak przedmioty metodologiczne i związane z teorią historii, takie jak: „Wprowadzenie do historii”, „Historia historiografii” i sama „Metodologia historii” stwarzają pewne możliwości, by odpowiedzieć na zapotrzebowanie merytorycznej, rozwijającej wiedzy połączonej z praktycznie użytecznymi umiejętnościami. 
Ponieważ wśród deklarowanych wartości towarzyszących studiowaniu wysokie miejsce zajmują wartości zorientowane na etyczny wymiar pracy historyka, w kontekście kommemoratywnym („ocalanie od zapomnienia”) oraz w odniesieniu do kwestii społecznego zaangażowania historiografii („praca historyka jako sposób „zrobienia czegoś pożytecznego”). Zajęcia z Historii historiografii stwarzają wiele możliwości ukazania relacji między narracją historyczną a społeczeństwem - roli narracji historycznej w definiowaniu problemów, a także w określaniu możliwości i sposobów ich rozwiązania. Prowadzącemu zajęcia na pewno nie zabraknie przykładów ani stosownej literatury, wystarczy wspomnieć chociażby długą tradycję społecznie zaangażowanej historiografii „emancypacyjnej” wypowiadającej się „w imieniu” grup wykluczanych z oficjalnego dyskursu i dyskursu kreującego tradycyjne źródła historyczne. W szczególności inspirująca wydaje się być tutaj historia kobiet - stosunkowo młoda jeszcze szkoła historiograficzna podejmująca zagadnienie podmiotowej obecności kobiet w historii. Tradycja ta, pomimo że istnieje od stosunkowo niedawna', ma już na swoim koncie bardzo znaczące i godne omówienia prace takie, jak monumentalne pięciotomowe dzieło „Histoire des femmes en Occident” (Paris 1990-1991) będące efektem pracy ponad siedemdziesięcioosobowego zespołu badawczego kierowanego przez Michelle Perrot i Georges’a Duby ${ }^{2}$. Wykładowca „Historii historiografii” jeżeli będzie miał szczęście natrafić na studentów zainteresowanych dyskusją nad etycznym wymiarem historiografii i rolą tego dyskursu w kształtowaniu indywidualnych i społecznych tożsamości, z dużą korzyścią poznawczą może zaczerpnąć z historiograficznej tradycji historii kobiet.

Kwestia rozwoju intelektualnego towarzyszącego studiom i badaniom historycznym jest zagadnieniem złożonym, gdyż można wskazać na bardzo wiele składowych „rozwoju intelektualnego”, które mogą być uwzględnione bądź pominięte w trakcie zajęć. Jeżeli jednak zgodzimy się, że rozwój intelektualny wiąże się z wysiłkiem umysłowym podejmowanym w celu rozwikłania coraz to bardziej złożonych problemów poznawczych wówczas możemy zauważyć, że i na tym polu zajęcia z „Historii historiografii” dostarczają wiele możliwości dla stymulowania rozwoju intelektualnego u uczestników zajęć. Wystarczy wspomnieć tutaj możliwość, jaką stwarza omawianie dziejów historiografii nauki. Historia nauki jest bardzo specyficzną subdyscypliną historiografii wymagającą łączenia kompetencji historyka ze znawstwem (lub przynajmniej dobrą orientacją) w zakresie naukowej dyscypliny, której dzieje są przedmiotem

Maria Solarska wskazuje tutaj lata 1970-1973 jako okres ukonstytuowania się historii kobiet w historiografii francuskiej przodującej pod tym względem na światowej scenie historiograficznej. M. Solarska, M. Bugajewski, Wspótczesna francuska historia kobiet, Bydgoszcz 2009, s. 28

2 Omówienie tej pracy w: M. Solarska, M. Bugajewski, Wspótczesna francuska historia kobiet, Bydgoszcz 2009, s. 127-139. 
badań. Wybitne i znaczące prace z historii nauki (a w szczególności historii medycyny) zawierają w sobie oprócz niezbędnej faktografii także rozumiejącą prezentację bardzo złożonych zagadnień związanych z postrzeganiem ludzkiej cielesności i relacji człowieka do otaczającego go świata przyrody. Partycypując w historiograficznym opisie dziejów nauki, partycypujemy także w złożonościach naukowych teorii będących przedmiotem opisu i aktorem dziejów rozwoju nauki. Wystarczy tutaj wspomnieć prace Georgesa Canguilhema a w szczególności jego „Etudes d'histoire et de philosophie des sciences” (Paris 1968), w którym francuski historyk nauki podejmuje bardzo złożoną refleksję na temat dynamiki historycznego rozwoju ludzkiej wiedzy o życiu. Filozoficzna głębia tej refleksji zmusza do bardzo rozwijającego wysiłku, a jednocześnie mamy do czynienia z Autorem, który nie traci kontaktu z historyczną empirią̧${ }^{3}$.

Powyższe uwagi w szczególny sposób dotyczą także historiografii filozofii, która będąc narracją historyczną jest również częścią filozofii a zatem interdyscyplinarną dziedziną badawczą. Historyk historiografii w trakcie prowadzonych przez siebie zajęć ma możliwość rozpoznania potrzeb studentów w zakresie rozwoju intelektualnego a także ich potencjału dla takiego rozwoju oraz zaproponowanie takiego wyboru lektur z obszaru historii nauki aby uczestnicy zajęć mogli być w kontakcie z założonymi koncepcjami naukowymi, których zrozumienie wymaga wysiłku będącego katalizatorem intelektualnego rozwoju.

Historia historiografii wraz z innymi zajęciami o metodologicznym profilu stwarzają wiele możliwości do wyjścia naprzeciw poznawczym i etycznym ambicjom studentów zadeklarowanym w przedstawionej na początku ankiecie. Problemem o większej złożoności jest jednak nawiązanie do oczekiwań dotyczących praktycznej użyteczności zajęć, szczególnie w kontekście oczekiwań współczesnego rynku pracy.

Zagadnienie to bardzo często pojawia się w politycznych i ministerialnych deklaracjach dotyczących szkolnictwa wyższego i jest permanentnie obecne w poświęconej tej tematyce publicystyce. Dla kształcenia humanistycznego - wymóg, czy też oczekiwanie by przygotowywać absolwentów do funkcjonowania na wysoce konkurencyjnym rynku pracy jest znacznie bardziej problematyczny niż dla inżynierskich kierunków studiów a także takich kierunków jak prawo, ekonomia czy nawet psychologia. Wynika to z prostego faktu, że o ile na przykład dla studiów ekonomicznych kwestia dostosowania programów nauczania do rynku pracy polega na ich uwspółcześnieniu i większym nasyceniu zagadnieniami empirycznymi (bieżącą praktyką gospodarczą), to dla historii jest to często nie tylko dostosowanie, lecz również zrewolucjonizowanie przekazu. Tradycja edukacji historycznej na wyższym szczeblu

3 Omówienie tej pracy i towarzyszących jej korzyści poznawczych w: T. Falkowski, Myśl i zdarzenie. Pojęcie zdarzenia historycznego w historiografii francuskiej XX wieku, Kraków 2013, s. 72-78. 
edukacji ma oczywiście związek z rynkiem pracy w tym zakresie, w którym wiąże się z kształceniem wykwalifikowanych nauczycieli i archiwistów. Problematyczny jest jednak związek treści dydaktycznych przekazywanych na zajęciach z przedmiotów nie związanych bezpośrednio z warsztatem pracy nauczyciela czy też archiwisty a zatem tych przedmiotów, które stanowią fundament akademickiej edukacji historycznej. Przedmioty metodologiczne, w tym przedmiot „Historia historiografii” (jak wiele innych wykładanych na kierunku studiów „Historia”) nie został pomyślany jako przedmiot kształcenia zawodowego tym samym wprowadzanie tam pod presją chwili zagadnień „rynkowych” stanowi zagrożenie dla jego akademickiej tożsamości. Jeżeli zatem jako wykładowcy „Historii historiografii” chcemy wyjść naprzeciw także wobec oczekiwania studentów związanego z „praktycznością” zdobywanych kwalifikacji należy (jak sądzę) zastanowić się czy w ogóle istnieje wiedza i umiejętności, która z jednej strony wzmacnia atrakcyjność naszych absolwentów na rynku pracy a z drugiej nieprzypadkowo towarzyszy badaniom i refleksji w polu problemowym dziejów historiografii. Jest to kwestia zasadniczego znaczenia, gdyż wprawdzie można wymyślić wiele sposobów wzbogacenia wykładu akademickiego o elementy, które są „rynkowe” (bądź przynajmniej sprawiają takie wrażenie), to jednak wprowadzanie ich bez związku z akademicką tradycją wykładanego przedmiotu jest ewidentnym podkopywaniem jego tożsamości.

Wiedza i umiejętności nauczane w ramach poszczególnych przedmiotów akademickiego wykładu bez wątpienia powinny być w pierwszej kolejności uzasadnione merytorycznie a następnie w ramach możliwości stwarzany przez tradycję danej dziedziny wiedzy dostosowane do okoliczności. Nasze stanowisko nie oznacza apologii modelu dydaktyki uniwersyteckiej ignorującego okoliczności społeczne i gospodarcze, lecz takiego, w którym istnieje świadomość potrzeby chronienia własnej tożsamości (czyli tożsamości tradycji uniwersyteckiej i tożsamości dziedzin wiedzy obecnych w uniwersyteckim nauczaniu), szczególnie istotna w czasach dynamicznych zmian cywilizacyjnych.

Elementem zasadniczym jest zatem nie tylko znalezienie wiedzy i umiejętności praktycznych, które mogą zostać wprowadzone do dydaktyki uniwersyteckiej, lecz także merytorycznego uzasadnienia ich obecności w tym wykładzie. Tradycja badań towarzyszących dydaktyce „Historii historiografii” jak również pozostałych przedmiotów metodologicznych (takich jak „Wprowadzenie do historii” i „Metodologia historii”) stwarza możliwości nie tylko stymulowania intelektualnego rozwoju studentów, lecz 
również przyswajaniu przez nich umiejętności praktycznie użytecznych i cenionych na rynku pracy co postaramy się uzasadnić poniższym przykładem.

Punktem wyjścia jest element praktyki badawczej historii historiografii jaką jest analiza recepcji, znaczenie tej praktyki omawia Violetta Julkowska w artykule „Badanie recepcji jako koncept w obszarze historii historiografii” ${ }^{4}$ wskazując tam literaturoznawczą i historiograficzną tradycję uzasadniającą podejmowanie badań recepcji. Jednym z czterech podstawowych typów recepcji podlegających badaniu jest jej najszerszy wymiar dotyczący najszerszej (nieprofesjonalnej) recepcji czytelniczej, jest on, jak przyznaje Autorka artykułu, trudny do badania gdyż w przeciwieństwie do czytelnictwa profesjonalnego nie pozostawia takich śladów jak cytowania, a zatem badanie często opiera się na źródłach pośrednich takich jak nakłady i ogólny poziom czytelnictwa $^{5}$. Współcześnie jednak, badanie ogólnej (nieprofesjonalnej) recepcji autorów prac historycznych i literackich jest zdecydowanie ułatwione gdyż wyszukiwanie i pozyskiwanie książek do lektury odbywa się z wykorzystaniem informacji umieszczonej w internecie (oferta wydawnicza i biblioteczna, recenzje, blogi, fora dyskusyjne) i jako takie pozostawia ślady w archiwach wyszukiwarek. Zasoby internetu zawierają w sobie olbrzymie ilości danych ilościowych dotyczących wszelkich aspektów ludzkiej działalności. Danych będących potencjalnymi źródłami historycznymi, także źródłami adekwatnymi dla refleksji nad dziejami historiografii. Elementem dziejów historiografii jest historia recepcji dzieł historycznych oraz kwestia zainteresowania ich autorami. Jednym z repozytoriów danych dotyczących tego zagadnienia są archiwa wyszukiwarek internetowych a w szczególności najpopularniejszej z nich przeglądarki „Google”.

Zajęcia „Historii historiografii”, na których omawiane jest zagadnienie współczesnej recepcji prac historycznych, może zatem zawierać warsztatowe elementy związane z pozyskiwaniem i analizą danych. Na najłatwiejszym poziomie, dostosowanym do mało ambitnych grup czy też studentów nie chcących się szczególnie angażować w pozyskiwanie praktycznych umiejętności, elementem zajęć może być po prostu wykorzystanie zaawansowanych narzędzi rozbudowanych wyszukiwarek internetowych, dostarczających informacji o najczęściej występujących zapytaniach. Nieco bardziej zaawansowanym elementem jest pobieranie informacji o częstotliwości występowania danego zapytania w postaci pliku .csv (comma separated variables/values) i jego opracowanie przy pomocy ogólnie dostępnego oprogramowania biurowego.

„Sensus Historiae”, T XVI (2014/3), s. 15-28.

5 „Sensus Historiae”, T. XVI (2014/3), s. 24. 
Na załączonej ilustracji widzimy wizualizację danych ilościowych opisujących częstotliwość występowania zapytania o historyka Joachima Lelewela wprowadzanego do wyszukiwarki google.com (dane są udostępniane od 2004 roku). Wykres został sporządzony przy pomocy programu napisanego w języku programowania Python ${ }^{6}$ dostępnego również dla każdego z trzech podstawowych systemów operacyjnych. Jego zaletą dostrzeżoną nie tylko przez programistów, lecz również naukowców prowadzących badania w wielu dyscyplinach, jest prostota składni oraz bogactwo bibliotek programistycznych czyli gotowych składowych, z których możemy „skomponować” program do analizy i wizualizacji danych pochodzących z naszej źródłowej kwerendy. Poniższy wykres został wykonany przy pomocy biblioteki „pandas” stworzonej dla naukowców operujących na danych liczbowych.? Oś Y ukazuje częstotliwość zapytań wprowadzonych do wyszukiwarki „Google”, oś X dynamikę zmian w czasie zachodzącą od 2012 do końca 2016 roku.

Podobną wizualizację sporządziliśmy w odniesieniu do danych dotyczących innego polskiego historyka, Karola Szajnochy:

Oprócz wizualizacji danych przedstawiających częstotliwość zapytań możemy na zajęciach $\mathrm{z}$ „Historii historiografii” przeprowadzić również analizę rozkładu wartości tych zapytań po to by zastanowić się nad zagadnieniem czy zainteresowanie danym historykiem ma charakter incydentalny (duża odległość wartości maksymalnej od wartości średniej), czy regularny. Poniżej prezentuję wykresy sporządzone również przy pomocy języka programowania Python oraz bibliotek „pandas" $i$ „seaborn”", obrazujące wspomniany wyżej charakter zainteresowania polskimi historykami Joachimem Lelewelem i Karolem Szajnochą.

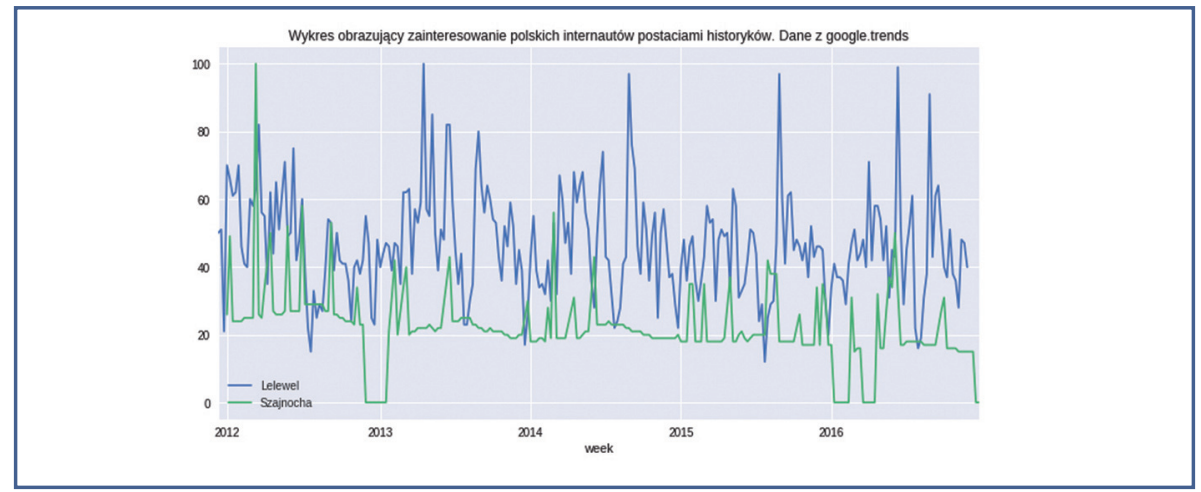

Ilustracja 1 Wykres zbiorczy ukazujący zainteresowanie historykami: ILelewelem i KSzajnochą, odrębne wykresy w załączniku 2.

6 https://www.python.org/

7 Wes McKinney, Python for Data Analysis, Cambridge-Tokyo 2013, s. 2-4.

8 http://seaborn.pydata.org/ 


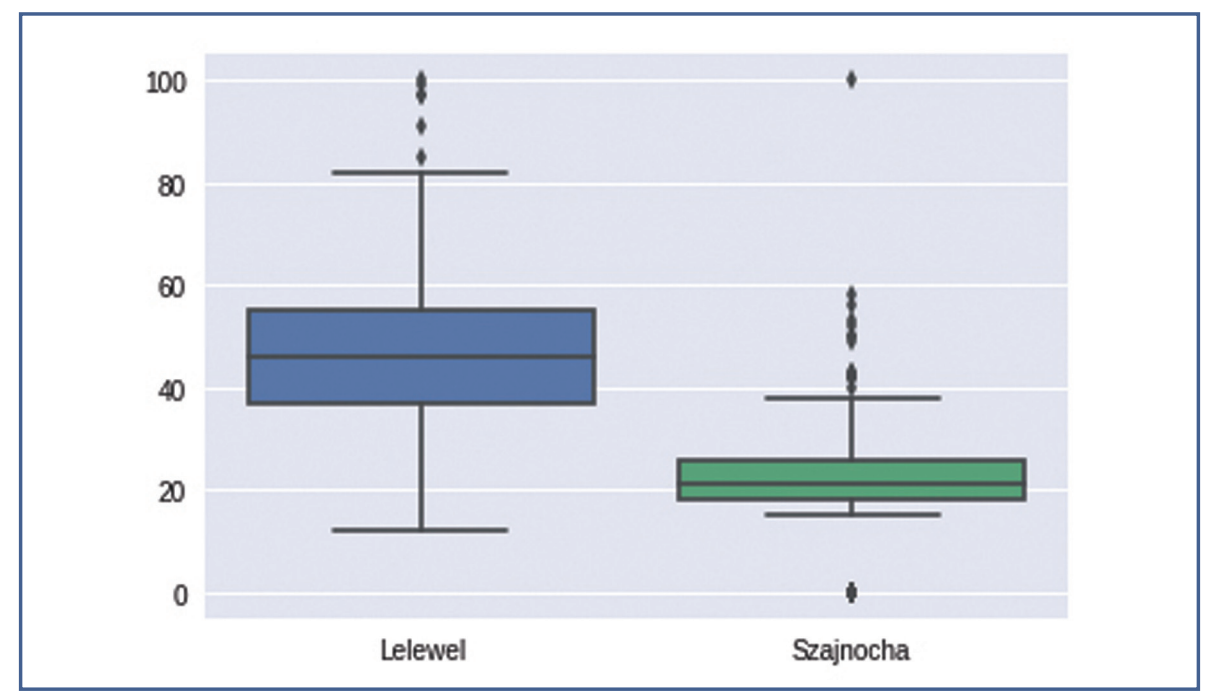

llustracja 2 Wykres zbiorczy ukazujące rozkład wartości zainteresowania historykami: lLelewelem i KSzajnochą, odrębne wykresy w załączniku 2.

Wykresy obrazują odchylenie wartości średniej od wartości ukazującej maksymalne natężenie a tym samym pozwalają zorientować się czy zainteresowanie Karolem Szajnochą w świetle ilościowych danych pochodzących z archiwum Google.trends ma charakter incydentalny czy permanentny. Podobny program zaprezentowany poniżej i dotyczący rozkładu natężenia zapytań dotyczących Joachima Lelewela wskazuje na znacznie bardziej permanentny charakter zainteresowania warszawskim historykiem (wykresy typu „boxplot”: silniejsze przesunięcie średniej w dół w przypadku Szajnochy niż Lelewela). Pełen kod źródłowy programu w załączeniu (DODATEK 2).

Wprowadzenie na zajęciach „Historii historiografii” elementów analizy danych ilościowych i pewnych elementów programowania nie jest tutaj, jak sądzimy, przejawem zgniłego kompromisu między tradycja akademicką i wymogami praktyczności gdyż nie jest przypadkowe i nieuzasadnione. Przeciwnie, wiąże się z potrzebami badawczymi dyscypliny jaką jest śledzenie i analiza recepcji historyków nie tylko w profesjonalnych publikacjach, lecz również w obszarze powszechnego zainteresowania. Jednocześnie dodatkową wartością, pozyskiwaną przez studentów na takich zajęciach, może być pewna wstępna orientacja w zakresie pozyskiwania i opracowywania informacji. Umiejętności te mogą być później przez studentów udoskonalane samodzielnie, lub w ramach seminarium, na którym można wprowadzić bardziej zaawansowane narzędzia do pozyskiwania danych (takie jak biblioteki języka python służące do tzw. webscrappingu) oraz ich analizy (przykładem może być zaawansowana biblioteka analizy 
języka naturalnego - nltk ${ }^{9}$ dostępna dla języka programowania python). Obecność na zajęciach z „Historii historiografii” technik i metod pozyskiwania i analizy danych (głównie danych ilościowych) niesie za sobą wiele korzyści, jednak niewolne jest również od zagrożeń. Nie wolno nam bowiem jest zapomnieć, że historia będąca użyję tutaj znanego sformułowania Marca Blocha - „nauką o ludziach w czasie” ${ }^{10}$ jest nauką, której pytania i problemy badawcze dotyczą fenomenów jakościowych. Materią refleksji historyka jest to czym żyje i jak żyje człowiek? Jak postrzega dobro i zło? Jak postrzega siebie i innych? Pytania te dotyczą pojęć i wartości, które można zrozumieć wyłącznie w kategoriach jakościowych. Wszelka analiza ilościowa, aczkolwiek potrzebna i pożyteczna, prędzej czy później będzie musiała być odniesiona do problemów badawczych historii, a zatem przełożona na kategorie jakościowe. Bogactwo metod ilościowych, wzrastające w logarytmicznym postępie wraz z rozwojem technologii cyfrowej i zasobów internetu, czyli ze wzrostem dostępności mocy obliczeniowej komputerów oraz ilości danych dostępnych do analizy, sprawia wrażanie otwartego skarbca wszelkiej wiedzy i takim może być faktycznie o ile znajdziemy pojęcia i kategorie pozwalające na połączenie danych ilościowych z problemami i pojęciami, którymi żyje człowiek, i które stanowią treść refleksji historycznej.

\section{DODATEK 1:}

WYNIKI BADAŃ ANKIETOWYCH: CELE, WARTOŚCI I POSTAWY ZWIĄZANE Z STUDIOWANIEM I PRZYGOTOWYWANIEM PRACY DYPLOMOWEJ

PRZYGOTOWA 1 PRZEPROWADZIt: Wiktor Werner

TERMIN PRZEPROWADZENIA BADAŃ: 2016

GRUPA BADANYCH: 70 osób (studenci historii UAM, kierunek historia - bez podziału na specjalności).

Ankieta zawierała 14 pytań jednokrotnego wyboru, w przypadku 11 pytań respondenci udzielili odpowiedzi, w których można wskazać wyraźną dominantę. Na pytania dotyczące celów i wartości związanych ze studiowaniem/sporządzaniem prac dyplomowych respondenci wybierali pomiędzy następującymi odpowiedziami:

- Utożsamiam się z tym stwierdzeniem.

- Nie utożsamiam się z tym stwierdzeniem, ale nie jest ono mi zupełnie obce.

- Zupełnie odrzucam ten punkt widzenia.

- Trudno powiedzieć, nie wiem.

9 http://www.nltk.org/

10 Bloch, Marc, Apologie pour l'histoire ou Métier d'historien, Paris 1949, digitalizacja: [www.uqac.ca/ Classiques_des_sciences_sociales/], s. 18. 


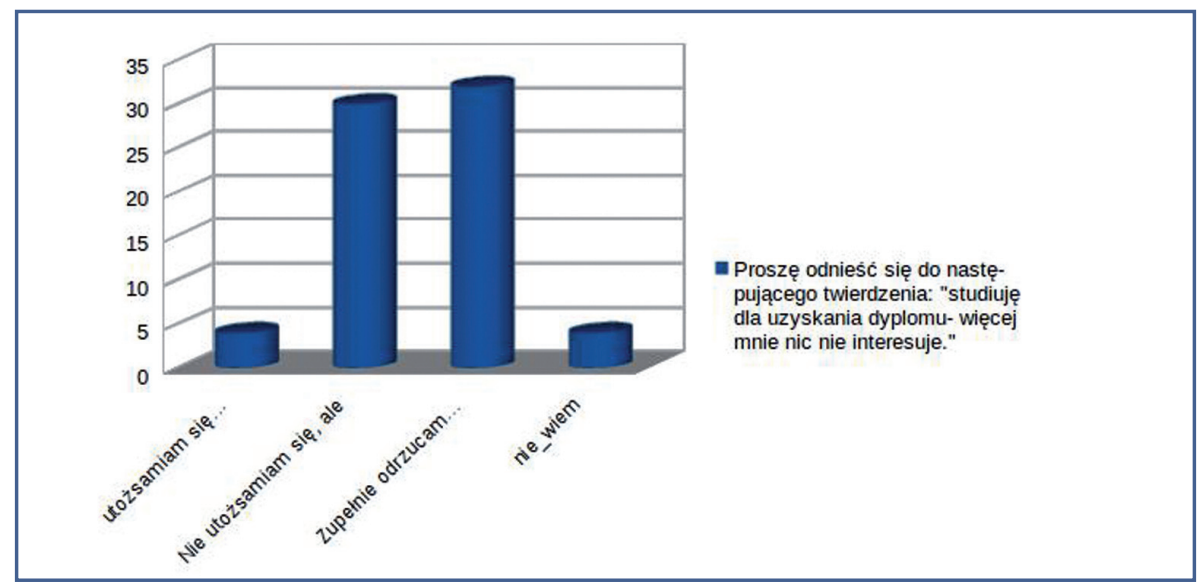

Ilustracja 3 Odpowiedzi na putanie 1

W prezentowanym pytaniu 62 osoby (łącznie $89 \%$ głosów) odrzuciło bądź zdecydowanie odrzuciło sugestię (odpowiednio 30 i 32 osoby), a jedynie 4 osoby (6\% głosów) zadeklarowało taką intencję studiowania. Odpowiedź na to pytanie koresponduje z wynikami uzyskanymi w kwestii podobnego pytania dotyczącego sporządzania pracy dyplomowej:

Pytanie 6: Proszę odnieść się do następującego twierdzenia: „piszę pracę dyplomową, aby mieć to z głowy.” W tym przypadku uzyskano podobne wyniki gdyż utożsamiało się ze wskazaną „wartością” 9\% badanych (6 osób) Nie utożsamiam się z tym stwierdzeniem, ale bez jednoznacznego odrzucenia $40 \%$ respondentów (28 osób) i tyle samo jednoznacznie odrzuciło ten punkt widzenia. Zatem bezwzględnie bądź względnie odrzuciło stwierdzenie „piszę pracę dyplomową aby mieć to z głowy” $80 \%$ respondentów (56 osób). Tendencja do odrzucenia minimalistycznego podejścia do studiowania i przygotowywania pracy dyplomowej ujawnia się również w odpowiedziach na kolejne pytania.

Dominantą jest tutaj odpowiedź pierwsza (akceptacja twierdzenia), którą wybrało 49 respondentów ( $84 \%$ głosów) przy 1 głosie odrzucającym tą wartość i 9 osobach (13\% głosów) zdystansowanych do niej. Tendencja ta jest także obecna w odniesieniu do zagadnienia przygotowywania pracy dyplomowej: 


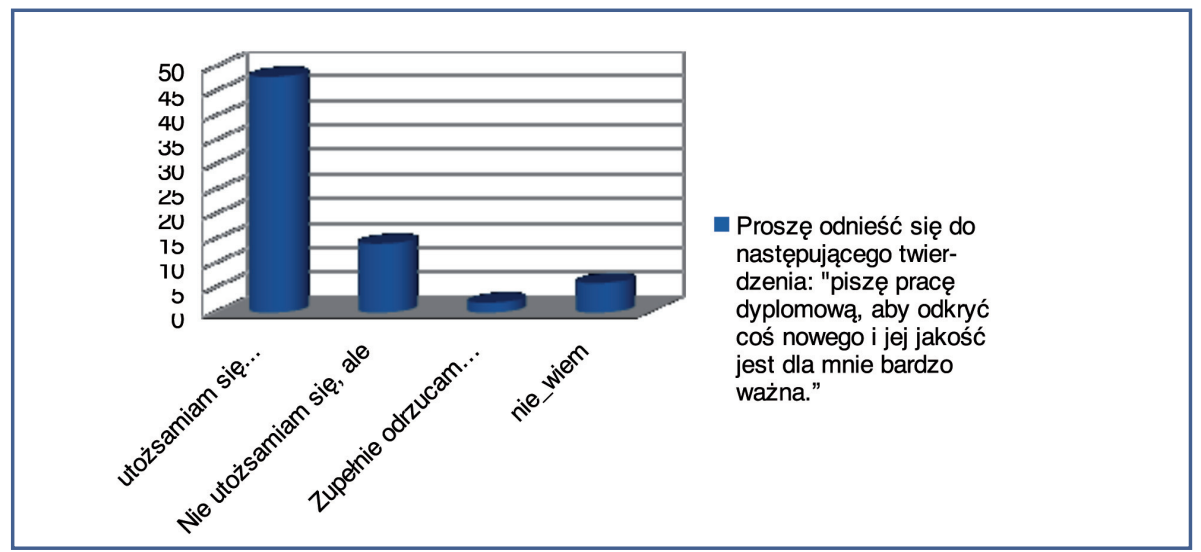

llustracja 4 Odpowiedzi na pytanie 7

Akceptacja wartości pro-jakościowej: 48 głosów na 70 oddanych (69\%), 2 osoby (3\%)odrzucily wartość, względne zdystansowanie do twierdzenia zadeklarowało 14 respondentów (20\% głosów). Jeszcze wyraźniejsza jest odpowiedź na kolejne pytanie.

W tym przypadku dominanta (deklaracja utożsamienia się ze wskazaną wartością) wynosi 79\% i 55 głosów przy 3\% i 2 głosach odrzucających tę perspektywę i 13\% i 9 osobach zdystansowanych.

Odpowiedzi na pytania ujawniają pro-jakościową orientację studentów i wskazują na wartości takie, jak: rozwój intelektualny oraz ambicję wzbogacenia istniejącej wiedzy własnymi badaniami i refleksją. Kolejną wartością, przywiązanie do której deklarują studenci, to chęć upamiętnienia godnych tego ludzi i wydarzeń:

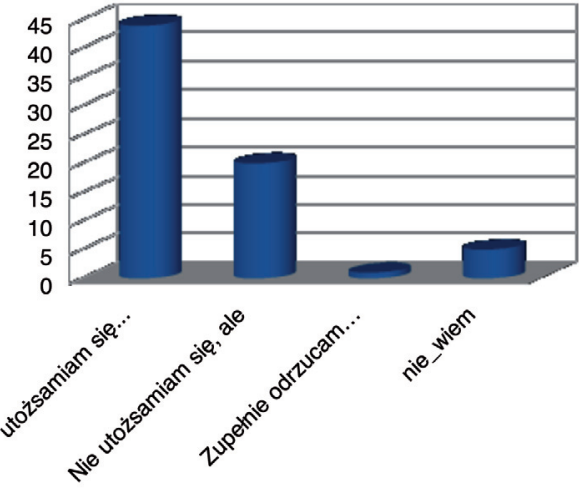

Proszę odnieść się do następującego twierdzenia: "piszę pracę dyplomową, aby upamiętnić ludzi i wydarzenia, które nie powinny zostać zapomniane."

llustracja 5 Odpowiedzi na pytanie 11 
Dominanta (akceptacja): 63\% i 44 głosy, bezwzględne odrzucenia wskazanej wartości zadeklarowała jedna osoba (ok. 1\%), zdystansowało się od niej 20 osób (odrzucenie 29\%). Podobnie wyniki kształtowały się w pytaniu dotyczącym generalnie altruistycznej motywacji studiowania:

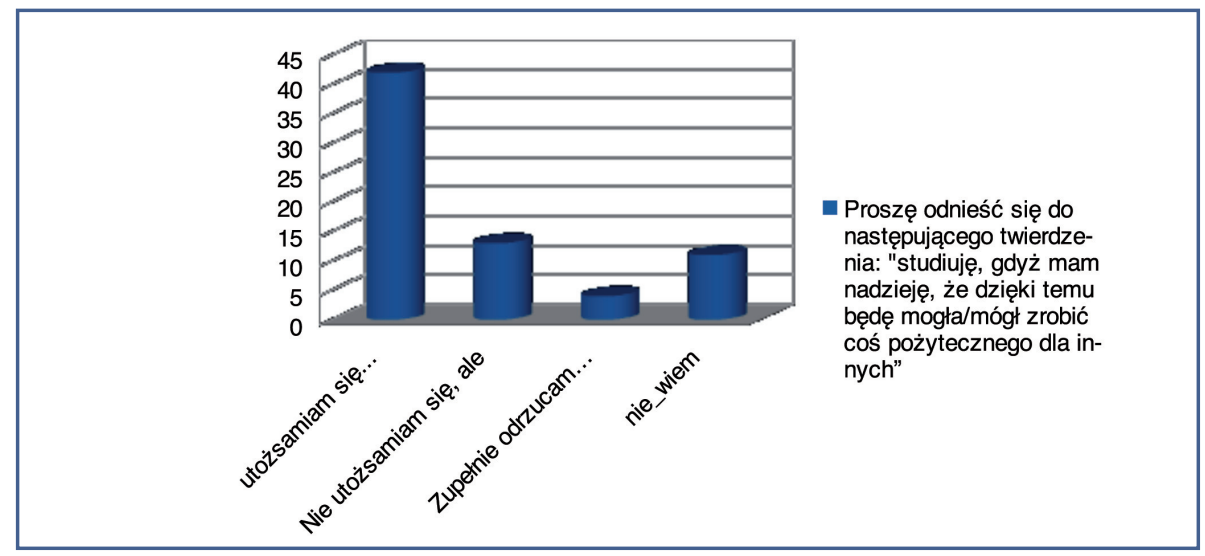

llustracja 6 Odpowiedzi na pytanie 5

gdzie z powyższym stwierdzeniem utożsamily się 42 osoby (60\%), odrzuciło je 4 osoby (6\%) a stanowisko zdystansowane wyraziło 13 osób (19\%).

Z podjęciem twórczego wysiłku wiąże się również oczekiwanie, że przyniesie on wymierne korzyści w postaci nabytych kwalifikacji, na co wskazują wyniki kolejnego pytania:

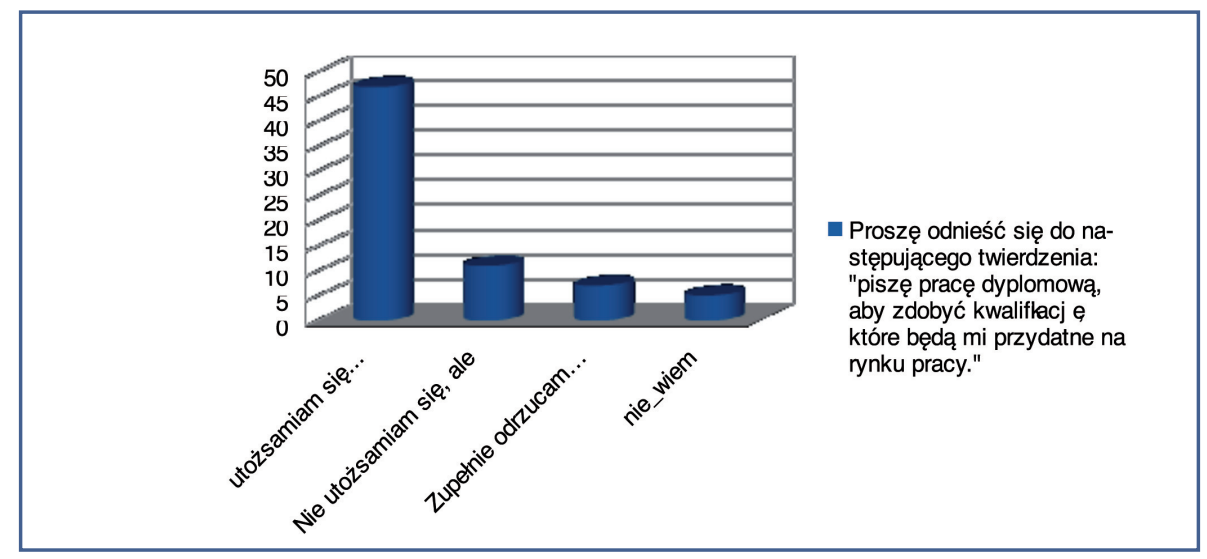

llustracja 7 Odpowiedzi na pytanie 12

gdzie akceptację dla wskazanego celu wykazało 47 osób (67\%), odrzuciło ten cel 7 osób (10\%), zaś postawę zdystansowaną zadeklarowało 11 osób (16\%). 
Znacznie mniejsza różnica między dominantą a pozostałymi odpowiedziami zachodziła w przypadku pytania o cel studiowania związany z realizacją celów natury towarzyskiej:

Akceptacja: 49\% i 34 głosy, odrzucenie: 9\% i 6 głosów, postawa zdystansowana: $33 \%$ i 23 głosy, a także wartości jaką jest przyjemne spędzanie czasu:

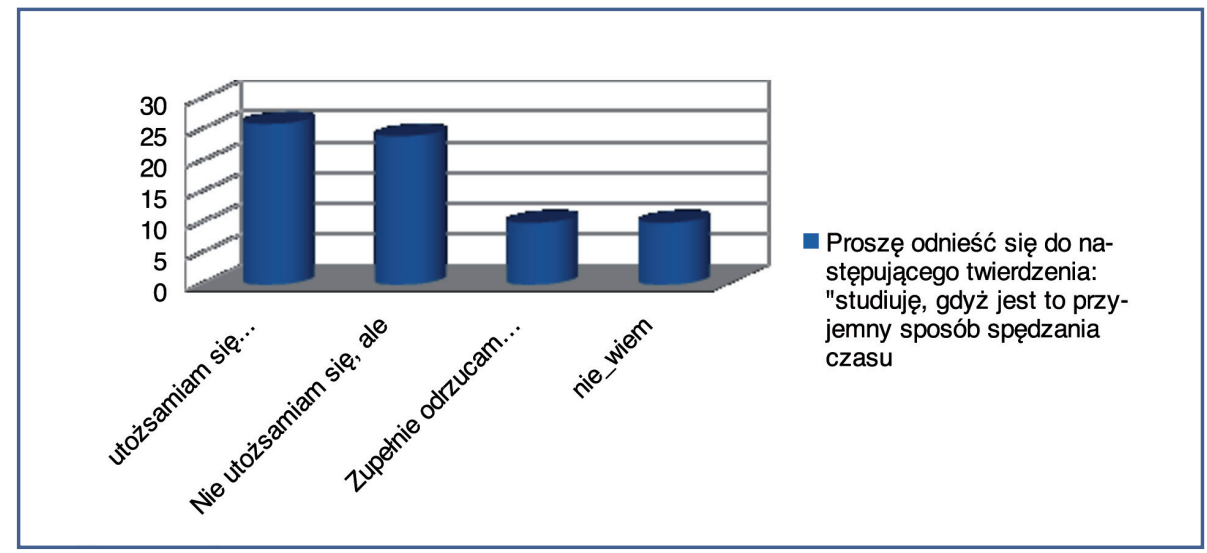

llustracja 8 Odpowiedzi na pytanie 4

gdzie akceptacja (dominanta) wyniosła 37\% i 26 głosów, odrzucenie 14\% i 10 głosów, a postawa zdystansowana $34 \%$ i 24 głosy.

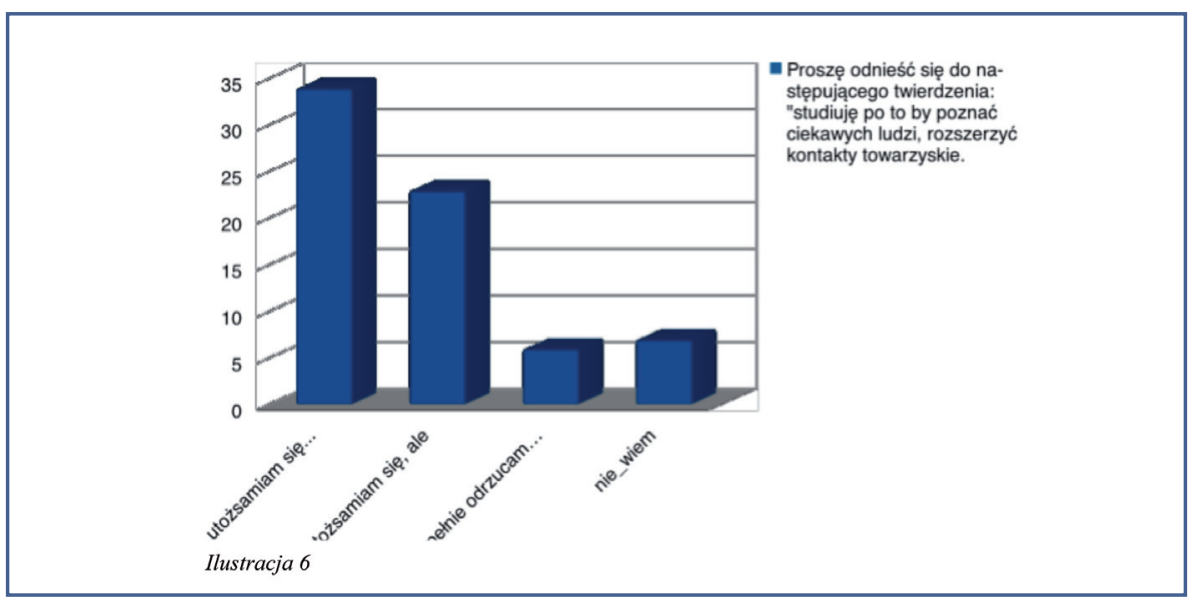

llustracja 9 Odpowiedzi na pytanie 3

Studenci wskazali również w swoich odpowiedziach to, że nie łączą praktyki pisania pracy dyplomowej z bezpośrednimi korzyściami finansowymi: 


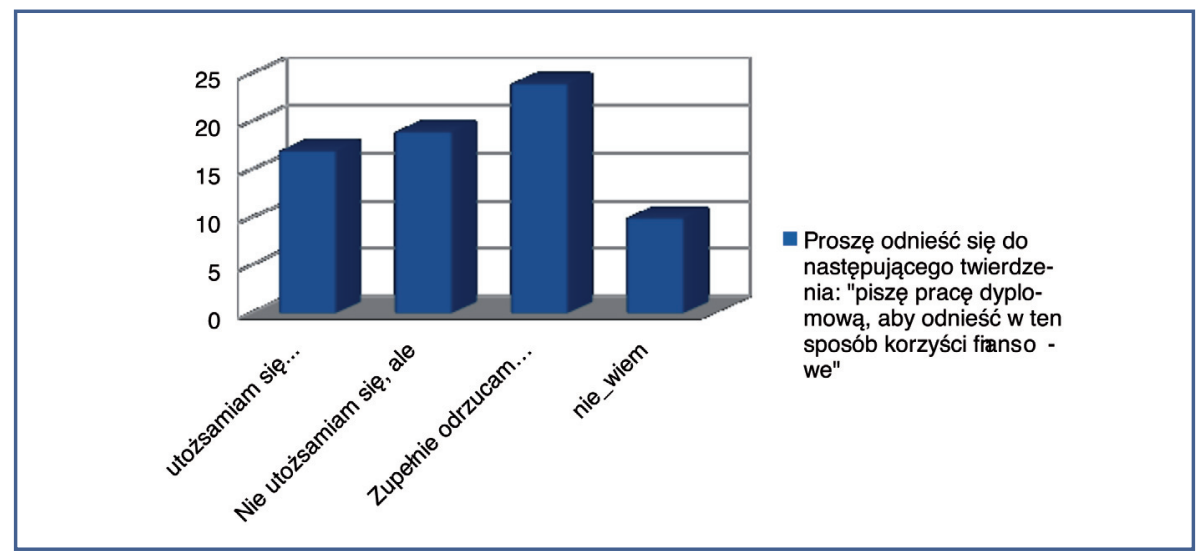

Ilustracja 10 Odpowiedzi na pytanie 13

Dominantą tym przypadku jest odrzucenie celu pozyskiwania korzyści finansowych: 34\% i 24 głosy, przy akceptacji celu na poziomie 24\% i 17 głosów oraz postawie zdystansowanej wyrażonej przez 27\% i 19 respondentów.

\section{DODATEK2}

In $[1]:$

import warnings

warnings.filterwarnings ( "ignore")

import matplotlib.pyplot as plt

import pandas as pd

import seaborn as sns

import numpy as $\mathrm{np}$

from matplotlib.patches import Ellipse, Polygon

from pandas.tools import plotting as pting

import sklearn as sci

\% matplotlib inline

In $[2]$ :

lelewel=pd.read_csv(,./histor_dane/lelewel.csv', parse_dates=[, week'], index_col='week' )

lelewel2=pd.read_csv( ,./histor_dane/lelewel2a.csv', parse_date$\mathrm{s}=\left[\right.$, month'], index_col='month' ${ }^{\prime}$ )

szajnocha=pd.read_csv(,./histor_dane/szajnocha2.csv', parse_date$\mathrm{s}=[$, month'], index_col='month' )

por=pd.read_csv('./histor_dane/compar1.csv', parse_dates=['month'], index_col='month' ')

In $[11]$ :

szajnocha.plot $($ figsize $=[8,6])$

Out $[11]$ :

<matplotlib.axes._subplots.AxesSubplot at 0x7f61933b27b8> 


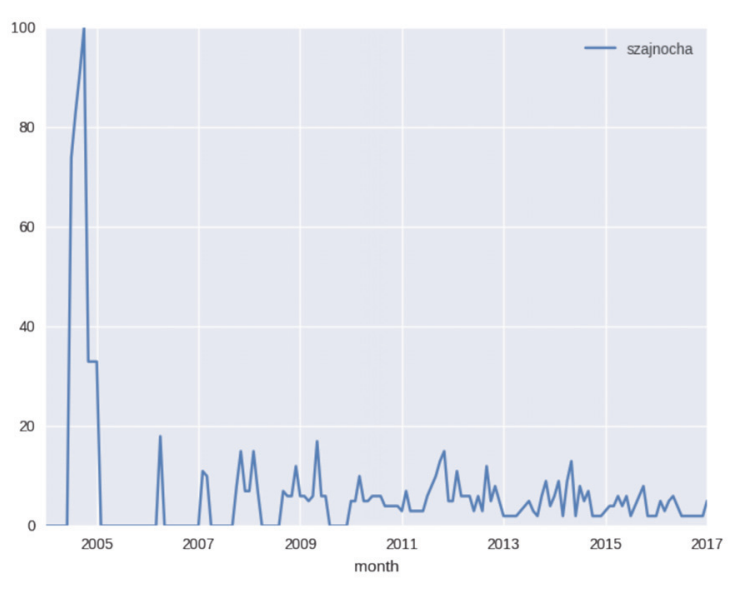

Ilustracja 11

In $[5]$ :

sns.boxplot (szajnocha.szajnocha)

Out [5]:

<matplotlib.axes._subplots.AxesSubplot at 0x7f6193059358>

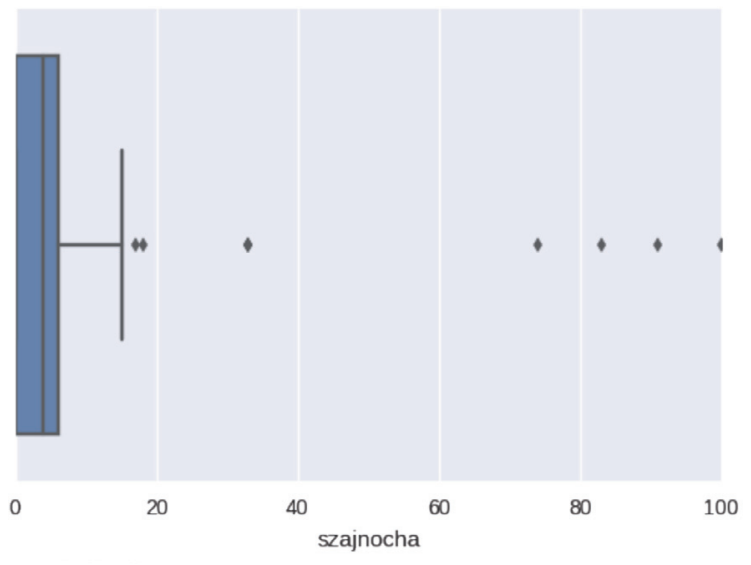

llustracja 12

In [7]:

sns.boxplot (lelewel2.lelewel)

Out[7]:

<matplotlib.axes._subplots.AxesSubplot at 0x7f6193578630> 


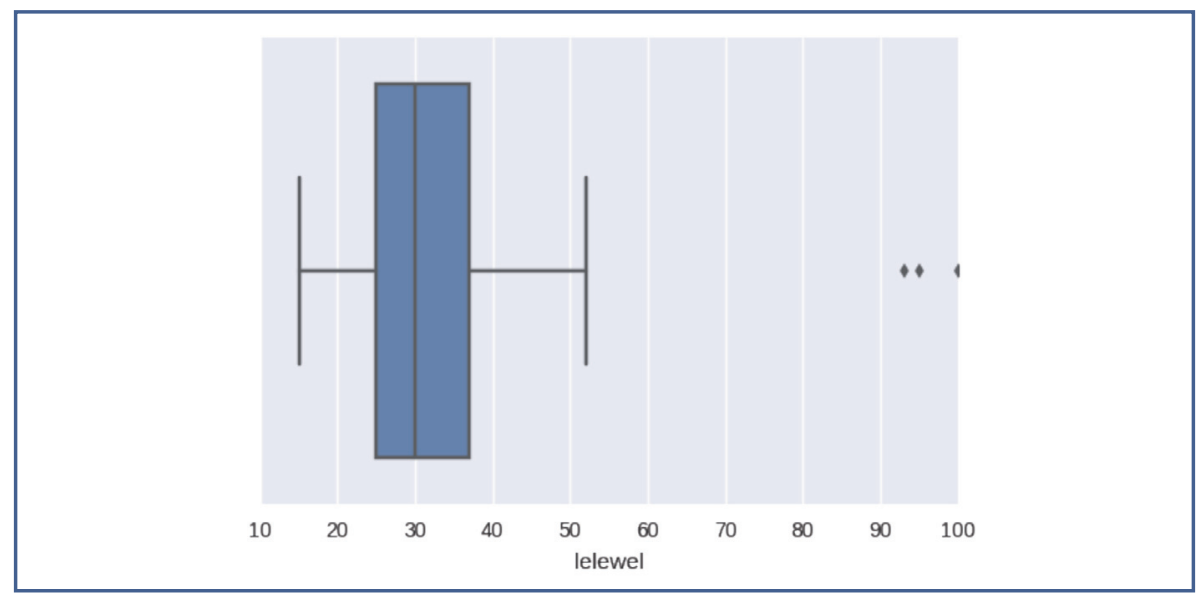

llustracja 13

In $[13]$ :

lelewel2 $\cdot$ plot $($ figsize $=[8,5])$

Out[13]:

<matplotlib.axes._subplots.AxesSubplot at 0x7f61935990f0>

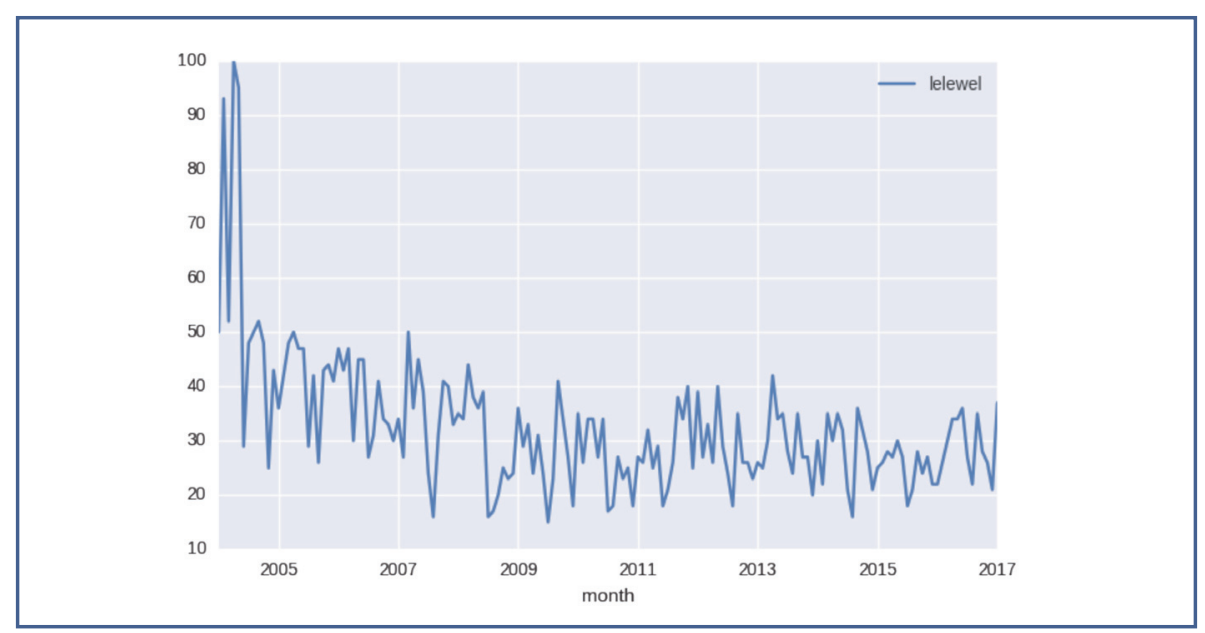

Ilustracja 14 